\title{
Genomic imbalances in 5918 malignant epithelial tumors: an explorative meta-analysis of chromosomal CGH data Michael Baudis
}

Address: Institute of Molecular Biology, University of Zurich, Winterthurerstrasse 190, CH-8057 Zurich, Germany

Email: Michael Baudis - mbaudis@gmail.com

Published: 18 December 2007

BMC Cancer 2007, 7:226 doi:10.1 186/147/-2407-7-226
Received: 26 April 2007

Accepted: 18 December 2007

This article is available from: http://www.biomedcentral.com/I47I-2407/7/226

(c) 2007 Baudis; licensee BioMed Central Ltd.

This is an Open Access article distributed under the terms of the Creative Commons Attribution License (http://creativecommons.org/licenses/by/2.0), which permits unrestricted use, distribution, and reproduction in any medium, provided the original work is properly cited.

\begin{abstract}
Background: Chromosomal abnormalities have been associated with most human malignancies, with gains and losses on some genomic regions associated with particular entities.

Methods: Of the 15429 cases collected for the Progenetix molecular-cytogenetic database, 5918 malignant epithelial neoplasias analyzed by chromosomal Comparative Genomic Hybridization $(\mathrm{CGH})$ were selected for further evaluation. For the 22 clinico-pathological entities with more than 50 cases, summary profiles for genomic imbalances were generated from case specific data and analyzed.

Results: With large variation in overall genomic instability, recurring genomic gains and losses were prominent. Most entities showed frequent gains involving $8 q 2$, while gains on $20 q, 1 q, 3 q, 5 p$, $7 q$ and $17 q$ were frequent in different entities. Loss "hot spots" included 3p, 4q, 13q, 17p and 18q among others. Related average imbalance patterns were found for clinically distinct entities, e.g. hepatocellular carcinomas (ca.) and ductal breast ca., as well as for histologically related entities (squamous cell ca. of different sites).

Conclusion: Although considerable case-by-case variation of genomic profiles can be found by $\mathrm{CGH}$ in epithelial malignancies, a limited set of variously combined chromosomal imbalances may be typical for carcinogenesis. Focus on the respective regions should aid in target gene detection and pathway deduction.
\end{abstract}

\section{Background}

The analysis of genomic abnormalities in malignant cell clones has been performed for decades. Introduced in the 1960s, the evaluation of stained metaphase preparations from tumor cells $[1,2]$ has been widely employed in basic research as well as in clinical practice. For analysis of complex karyotypes, direct chromosomal inspection was recently enhanced through multicolour in-situ hybridization techniques: combinatorial multi-fluor FISH (M-FISH [3]) and multicolour spectral karyotyping (SKY [4]).
In contrast to traditional or enhanced cytogenetic analysis, molecular-cytogenetic methods rely on tumor DNA as starting material for the exploration of genomic abnormalities. While fluorescent in-situ hybridization (FISH $[5,6])$ allows for the detection of single or few numerical and structural genomic features in non-dividing cells, Comparative Genomic Hybridization (CGH $[7,8]$ ) permits the screening of the whole tumor genome for regional imbalances in the DNA content. Since CGH is based on the hybridization of tumor and reference DNA to standardized normal metaphase spreads, the spatial 
resolution of this technique is limited to several megabases [9]. Also, the involvement of presumptive target genes can only be inferred from the positional comparison of the genomic ratio profiles to the underlying chromosomal matrix. However, recent molecular-cytogenetic screening techniques (array-or matrix-CGH [10-12]) have the potential for direct identification of oncogenetic target genes.

Based on the comparably easy access to dividing tumor cells, and the early reognition of specific cytogenetic aberrations in some entities [13-15], metaphase analysis has been especially successfull in acute leukemias (review e.g. in [16]) and other hematologic malignancies. This has been reflected in the content of the Mitelman Database of Chromosome Aberrations in Cancer [17], in which hematologic neoplasias account for $73 \%$ of the database content (approx. 40,000 cases), while epithelial tumors constitute only $12 \%$ (approx. 6,600 cases). In contrast, especially through it's application to the genomic screening of frozen and archival tissue, the potential of CGH for the analysis of solid tumors had been recognized early on $[7,18]$.

Some previous reviews of CGH data have either reported on specific types of aberrations $[19,20]$ or were focused on solid tumors [21] or hematologic malignancies [22]. Struski et al. [23] provided a census of 11,984 solid tumors and hematologic malignancies analyzed by CGH. Since in the majority of publications data is presented as summary information (e.g. percentage of frequently involved chromosomal regions), these data reviews were able to develop a granular overview of the major regions frequently imbalanced in different tumor entities. Recently, Myllykangas et al. [24] provided an overview of genomic gain/amplification patterns, thereby omitting genomic losses. The study covered a large panel of human neoplasias, based on more than 4500 single cases. The authors were able to show a general relation genomic amplification patterns to general histo-pathological features, but could not prove overall relation of hot-spot sites to some known genetic features.

The current study attempts a descriptive overview of genomic imbalances in epithelial neoplasias, based on published CGH data. Starting point for the data exploration is the Progenetix molecular-cytogenetic database [2527], which was initiated in December 2000 to collect all published cancer related CGH data and make it available for reference and research purposes. In contrast to other CGH data assembly attempts, but comparable to the Mitelman Database of Chromosome Aberrations in Cancer, complete experimental results are collected on a caseby-case basis. Publications describing (molecular-) cytogenetic analyses of tumor samples and established cell lines are mined for case specific annotation of the experimental results. Focus is the exhaustive collection of chromosomal CGH data, with occasional inclusion of results from Metaphase banding, SKY and M-FISH data, as well as the recent addition of array or matrix CGH $[10,28]$ results.

The detailed discussion of identified or suspected target genes in the different chromosomal regions is not part of this study. However, some examples of genes with oncogene and tumor suppressor function, respectively, will be mentioned.

\section{Methods}

As of 2006-12-04, 15429 cases from 609 publications had been included into the Progenetix database. Of those, 13818 had been analyzed by chromosomal CGH, either alone or in combination with Metaphase analyses techniques ( 355 cases). Minimum requirement for addition to the database was the availability of case specific data for the complete (molecular-) cytogenetic analysis result and clinical diagnosis. In most cases, locus information was available or could be inferred. Additional data (grading, staging/TNM, age, gender, follow-up parameters) was recorded if accessible. As main disease descriptors, diagnosis and locus information was recoded to ICD-O-3 standard [29], based on the available information.

For the purpose of this article, cases ascribed to epithelial origin (ICD-O 8010/x-8780/x) were selected for further analysis. This base dataset comprised 6899 cases, collected from 254 publications. The oldest included data was from 1994 [30], the latest from 2006 [31]. The largest number of cases was found in a report about skin neoplasias (169 cases; [32]), followed by an extensive comparison of BRCA1 and BRCA2 mutated breast carcinomas (132 cases; [33]). Only 8 articles were single case reports.

To limit the bias in disease entities frequently analyzed in pre-malignant stages, only the 5918 clearly malignant epithelial neoplasias were selected (ICD-O-3 $\mathrm{xxxx} / 2$ and $\mathrm{xxxx} / 3$ ). For comparative purposes, common clinicopathological disease categories were generated through a combination of diagnostic and locus codes (Table 1). Only the 22 entities with more than 50 cases were analyzed separately, while 377 cases were not assigned to one of these entities.

During database entry, CGH results were converted to standard "rev ish" ISCN 1995 format. This procedure contained software based syntax errors checking. The corrected "rev ish" data was processed by dedicated software [27] implemented in the Perl scripting language [34] using complex Regular Expression based parsing algorithms. Data matrices were generated, containing the 
Table I: Distribution of 5918 malignant epithelial tumors by clinico-pathological entities, sorted by frequency of occurrence.

\begin{tabular}{|c|c|c|c|}
\hline Diagnosis & ICD-O-3 codes $(1)$ & Locus code(s) & No. of cases \\
\hline Breast carcinoma & $81 x x \ldots 86 x x$ & $\mathrm{C} 50$ & 667 \\
\hline Prostate carcinoma & $814 x$ & C6I & 600 \\
\hline Gastric carcinoma & $81 x x \ldots 86 x x$ & $\mathrm{Cl} 6$ & 529 \\
\hline Ovarian carcinoma & $81 x x \ldots 86 x x$ & C56 & 449 \\
\hline Colorectal adenocarcinoma (CRC) & 8140,8480 & $\mathrm{Cl}, \mathrm{Cl} 8$ & 430 \\
\hline Hepatocellular adenocarcinoma (HCC) & $817 x$ & $\mathrm{C} 22$ & 371 \\
\hline Head-neck squamous cell carcinoma (HNSCC) & 8070 & $\begin{array}{l}\mathrm{C} 01, \mathrm{C} 09, \mathrm{C} 06, \mathrm{Cl} 0, \mathrm{Cl} 2, \mathrm{Cl} 3 \\
\mathrm{Cl} 4, \mathrm{C} 30, \mathrm{C} 32\end{array}$ & 339 \\
\hline Thyroid carcinoma & $81 x x \ldots 87 x x$ & $\mathrm{C} 73$ & 314 \\
\hline Non-small cell lung carcinoma (NSCLC) & $81 x x \ldots 86 x x$, excl. $804 I, 8045,824 x$ & $\mathrm{C} 34$ & 254 \\
\hline Cervical carcinoma & $81 x x \ldots 86 x x$ & $\mathrm{C} 53$ & 226 \\
\hline Esophagus carcinoma (ES) & $81 \times x \ldots 86 x x$ & $\mathrm{CI}$ & 209 \\
\hline Renal carcinoma (RCC) & $81 \times x \ldots 86 x x$ & C64 & 195 \\
\hline Nasopharynx carcinoma (NPC) & 8010,8070 & $\mathrm{CII}$ & 177 \\
\hline Bladder carcinoma & $81 x x \ldots 86 x x$ & $\mathrm{C} 67$ & 169 \\
\hline Neuroendocrine ca. and carcinoid (NE) & $824 x$ & (all) & 138 \\
\hline Melanocytic (MEL) & $872 x \ldots 877 x$ & (all) & 99 \\
\hline Pancreas adenocarcinoma (PAC) & $814 x$ & $\mathrm{C} 25$ & 88 \\
\hline Cholangio carcinomas & $816 x$ & $\mathrm{C} 221, \mathrm{C} 24$ & 63 \\
\hline Small cell lung carcinoma (SCLC) & 8041,8045 & C34 & 63 \\
\hline Endometrial carcinoma & $81 x x \ldots 86 x x$ & C55 & 56 \\
\hline Vulva carcinoma & $81 x x \ldots 86 x x$ & C5I & 53 \\
\hline Squamous malignancies of the skin (SQS) & $807 x$ & C44 & 52 \\
\hline
\end{tabular}

377 tumors from entities with $<50$ cases were omitted from this list. (I) ICD codes and locus codes are listed as used for automatic assignment of cases to the disease groups; groups do not necessarily contain cases assigned to the whole range of ICD codes.

imbalance status ("1" = gain, "-1" = loss, "2" = high level gain) for each of 862 chromosomal bands (UCSC Genome Bioinformatics [35], Golden Path mapping, May 2004 edition), or subsets thereof.

For statistical analysis, software packages available as part of the Bioconductor [36] project for the R programming language [37] were used. Visualization of genomic imbalance profiles was performed by custom Perl routines using the GD.pm interface [38] to the GD graphics library [39]. As a robust measure for genomic instability, the number of chromosomes per case with one or more imbalanced segments was determined.

\section{Results and Discussion}

In the base data set comprised of 5918 malignant cases analyzed by $\mathrm{CGH}$, breast carcinomas and precursor lesions constituted the largest subgroup, followed by neoplasias of the prostate gland and stomach (Table 1). The median aberration number per case (number of chromosomes with at least one abnormal segment) showed a wide range (Figure 1 ), from 0 (squamous skin neoplasias, thyroid carcinomas) to 12 (small cell lung carcinomas; SCLC). For some of the entities at the low end of this spectrum, a certain bias through frequent biopsies at early stages can be suspected (e.g. tumors of skin, thyroid, pros- tate), although pre-maligant tumors had been excluded from the analysis.

\section{Imbalance hot spots in clinico-pathological entities}

In the overall aberration profile, gains on chromosomal band $8 q 24$ represented the most common imbalance, followed by gains involving regions on $20 q, 1 q, 3 q, 17 q$, $7(q)$ and 5p, as well as other changes (Figure 2).

In the following overview, the most frequent regions involved in genomic imbalances are listed, with detailed locus and frequency information for regional hot-spots. Since overall aberration frequencies vary greatly between entities, no absolute cut-off values (e.g. $10 \%$ or $20 \%$ ) were used when selecting these regions. Instead, genomic regions with clear separation from overall background in the imbalance histograms were selected for each entity and sorted in descending frequency of occurrence. Gains and losses were evaluated separately.

For each entity, few outstanding observations are discussed and selected literature is provided. Histologic subtypes are only mentioned in few entities. Because not all involved regions can be discussed here with respect to putative genetic targets, a selection of well characterized oncogenes and tumor suppressor genes with involvement in epithelial neoplasias is provided as part of Table 2. 


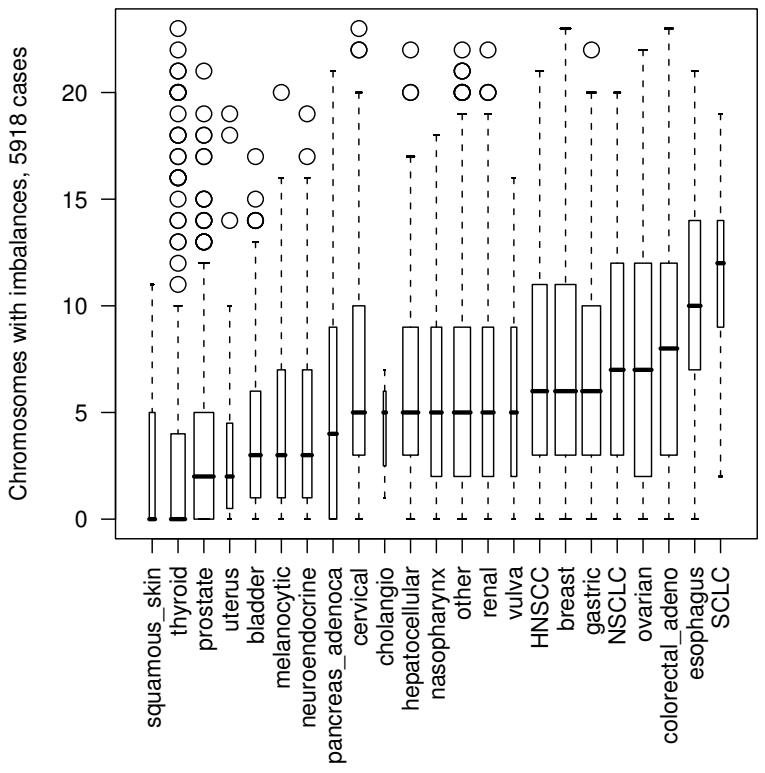

Figure I

Number of imbalanced chromosomes for different tumor loci as indicator for overall genomic instability, in 5918 malignant epithelial tumors. The box plots indicate the median and distribution of chromosomes in each tumor karyotype, with total or partial genomic imbalances. Only malignant cases (ICD-code \#\#/2 or \#\#\#/3) were analyzed.

Detailed aberration profiles for each entity can be found in the Additional file 1.

Breast carcinoma (667 cases)

Gains: 1q31 (50.8\%), 8q23 (47.3\%), 17q24 (31,2\%), $20 \mathrm{q}(30.9 \%), 16 \mathrm{p}, 11 \mathrm{q} 13,19,3 \mathrm{q}$

Losses: 16q (30\%), 8p23 (26.1\%), 17p13 (23.5\%), 11q23 $(23.1 \%), 13 q 21(22.8 \%)$

In breast carcinomas, gains on $1 \mathrm{q}$ and losses on $16 \mathrm{q}$ constitute the most frequent copy number changes of each quality. In the literature, a cytogenetic subtype with com- bination of these imbalances and few other genomic changes has been associated with histology of well differentiated DCIS [40] and a favorable prognosis [41]. Interestingly, gains on $11 \mathrm{q} 13$ and $12 \mathrm{q} 24$ were associated with higher metastasis-free survival in another study [42], which also associated multiple imbalances with a bad prognosis.

Although ERBB2 has been a known and clinically relevant [43] amplification target on 17q, distinct amplicons mapping telomeric to the ERBB2 locus have been described [44].

Prostate carcinoma (600 cases)

Gains: 8q24 (23\%), 7, X

Losses: 8p21 (32.3\%), 13q21 (26.5\%), 6q16 (18.5\%), $16 \mathrm{q}(23), 5 \mathrm{q}(21)$

In contrast to other adenocarcinomas, and accounting for the overall low copy number variations, prostate ca. usually lack the 1q gains frequent in most carcinoma entities. While Mattfeldt et al. [45] showed a correlation of 8p loss to higher tumor stage, the negative prognostic impact of gains of $8 \mathrm{q}$ and chromosome 7 in was reported from bioptic samples [46] and early tumors [47]. A meta analysis of published copy number data recently was provided by Sun et al. [48].

\section{Gastric carcinoma (529 cases)}

Gains: 20q12 (36.1\%), 8q23 (31.7\%), 17q21 (21.2\%), 7 (up to $20.8 \%$ ), 13q22q31, 1q, 3q, 5p, 11q13, X

Losses: 17p13 (24.4\%), 19p (18\%), 18q (16.6\%), 1p, 3p, $4,5 q, 9 p, 12 q, 16$

For most chromosomes, an overall background of $4-10 \%$ of gains as well as losses can be found. In gastric carcinomas as well as in some other entities, 8q gains have shown their maximum at 8q23, proximal to the c-myc locus [49], implying a hitherto unidentified target.

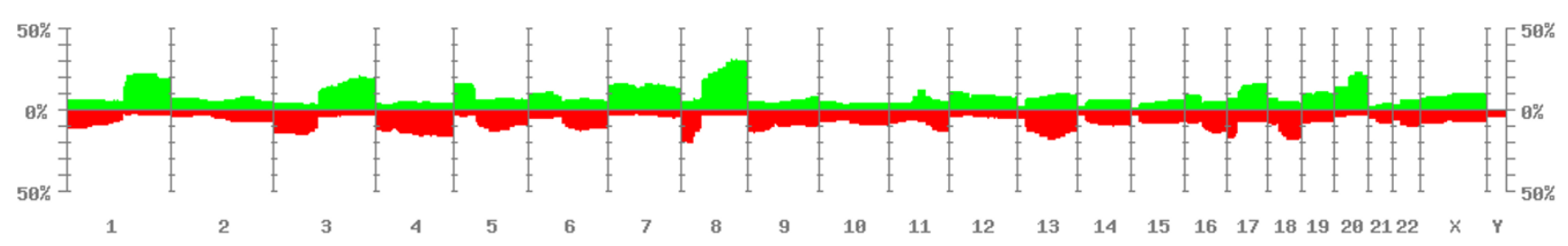

Figure 2

Overall imbalance pattern from all cases. For each chromosomal band ( 862 bands resolution) the percentage of cases with gains (green, upward) and losses (red, downward) is indicated. 
Table 2: Occurrence of most common imbalances in different epithelial neoplasias by CGH

\begin{tabular}{|c|c|c|c|}
\hline Regional imbalance & Most frequent* & Above background & Putative targets** \\
\hline $\begin{array}{l}\text { enh(lq) } \\
\text { occuring in most carcinoma } \\
\text { types }\end{array}$ & $\begin{array}{l}\text { Breast, ovary, HCC, cervix, NPC, MEL, } \\
\text { endometrial, vulva }\end{array}$ & $\begin{array}{l}\text { Gastric, CRC, HCC, HNSCC, NSCLC, ES, } \\
\text { RCC, bladder, PAC, SCLC, SQS }\end{array}$ & ABL2, ETV3 \\
\hline $\operatorname{dim}(3 p)$ & $\begin{array}{l}\text { HNSCC, NSCLC, cervix, ES, RCC, NE, } \\
\text { MEL (whole chr. 3), SCLC, vulva, SQS }\end{array}$ & Gastric, PAC & FHIT, MLHI \\
\hline $\begin{array}{l}\text { enh(3q) } \\
\text { maxima at 3q26q27 (except } \\
3 q 25 \text { in NPC) }\end{array}$ & $\begin{array}{l}\text { Ovary, HNSCC, NSCLC, cervix, ES, } \\
\text { NPC, SCLC, endometrial, vulva, SQS }\end{array}$ & Gastric, RCC, PAC & BCL6, PIK3CA \\
\hline $\begin{array}{l}\operatorname{dim}(\mathbf{4 q}) \\
\text { frequently whole chromosome }\end{array}$ & $\begin{array}{l}\text { Ovary, HCC, NSCLC, cervix, ES, bladder, } \\
\text { cholangio, SCLC }\end{array}$ & Gastric, CRC, HNSCC, RCC, PAC, & PRDM5 \\
\hline $\operatorname{enh}(5 p)$ & Thyroid, NSCLC, cervix, & $\begin{array}{l}\text { Gastric, ovary, CRC, HCC, HNSCC, ES, } \\
\text { bladder, NE, PAC, cholangio, vulva }\end{array}$ & CDH6, TERT \\
\hline $\operatorname{dim}(5 q)$ & Ovary, NSCLC, & $\begin{array}{l}\text { Prostate, gastric, HNSCC, ES, bladder, } \\
\text { cholangio, }\end{array}$ & APC, MCC \\
\hline $\operatorname{enh}(6 p)$ & HCC, MEL & $\begin{array}{l}\text { Ovary, NSCLC, cervix, ES, bladder, } \\
\text { cholangio, SCLC, vulva }\end{array}$ & E2F3, ID4 \\
\hline $\begin{array}{l}\operatorname{dim}(6 q) \\
\operatorname{maxima}_{6 q 24 q 27} \text { at } 6 q 16 q 21 \text { or }\end{array}$ & Prostate, RCC, MEL & $\begin{array}{l}\text { Ovary, HCC, NSCLC, cervix, bladder, NE, } \\
\text { PAC, cholangio, SCLC }\end{array}$ & CCNC \\
\hline $\begin{array}{l}\operatorname{enh}(7) \\
\text { frequently whole } 7 \text {, mostly } \\
\text { max. on } 7 q\end{array}$ & Prostate, thyroid, ES, RCC & $\begin{array}{l}\text { Gastric, ovary, CRC, HCC, HNSCC, } \\
\text { bladder, MEL, PAC }(7 p>7 q) \text {, cholangio } \\
(7 p>7 q)\end{array}$ & 7p: EGFR 7q: ABCBI, MET \\
\hline $\operatorname{dim}(8 p)$ & Breast, prostate, CRC, HCC & $\begin{array}{l}\text { Ovary, HNSCC, NSCLC, ES, RCC, } \\
\text { bladder, PAC, SCLC, vulva }\end{array}$ & DLCI, MSRI, N33 \\
\hline $\begin{array}{l}\text { enh(8q) } \\
\text { ubiquitously high (exception } \\
N E \text { and thyroid) }\end{array}$ & $\begin{array}{l}\text { Breast, prostate, ovary, CRC, HCC, } \\
\text { HNSCC, NSCLC, ES, RCC, bladder, MEL, } \\
\text { PAC, cholangio, endometrial, vulva }\end{array}$ & Cervix, NPC, SCLC, SQS & MYC \\
\hline $\begin{array}{l}\operatorname{dim}(9 p) \\
9 p \text { or whole } 9\end{array}$ & HNSCC, bladder, PAC, SQS & $\begin{array}{l}\text { Gastric, NSCLC, ES, RCC, NPC, MEL, } \\
\text { SCLC }\end{array}$ & ARF, CDKN2A \\
\hline $\begin{array}{l}\text { enh(I IqI 3) } \\
\text { frequently distinct (high-level) } \\
\text { gain }\end{array}$ & HNSCC & $\begin{array}{l}\text { Breast, gastric, ovary, NSCLC, ES, NPC, } \\
\text { bladder, MEL, PAC, cholangio }\end{array}$ & CCNDI, FGF3 \\
\hline $\operatorname{dim}(1$ lq23qter) & NPC, NE, vulva & Breast, HNSCC, cervix, ES, MEL, SCLC & $\begin{array}{l}\text { ATM(II q22), (LOHIICR2 } \\
\text { A, TSGII) }\end{array}$ \\
\hline $\begin{array}{l}\operatorname{enh}(12 p) \\
\text { frequently whole 12; slight } \\
\text { max. on } 12 p\end{array}$ & NPC & $\begin{array}{l}\text { Ovary, CRC, HNSCC, NSCLC, ES, RCC, } \\
\text { PAC, vulva }\end{array}$ & $\begin{array}{l}\text { I2p: CDK2, CDK4, GLI, } \\
\text { KRAS I 2q: MDM2 }\end{array}$ \\
\hline $\begin{array}{l}\operatorname{dim}(\mid 3 q) \\
\text { mostly }|3 q| 4 q 2 \mid\end{array}$ & $\begin{array}{l}\text { Prostate, HCC, thyroid, bladder, NE, } \\
\text { PAC, SCLC, endometrial }\end{array}$ & $\begin{array}{l}\text { Breast, gastric, ovary, HNSCC, NSCLC, } \\
\text { cervix, ES, RCC, NPC (max. at I I } 331 \text { ), } \\
\text { MEL, CRC, vulva }\end{array}$ & BRCA2, RBI, STARDI3 \\
\hline $\operatorname{dim}(16 q)$ & Breast, NPC & Prostate, gastric, HCC, SCLC & CDHI, ATBFI \\
\hline $\operatorname{dim}(17 p)$ & Breast, gastric, CRC, cholangio, SCLC & $\begin{array}{l}\text { Ovary, HCC, NSCLC, cervix, ES, RCC, } \\
\text { NPC, bladder, PAC, SQS }\end{array}$ & TP53 \\
\hline $\operatorname{enh}(I 7 q)$ & $\begin{array}{l}\text { Breast, gastric, bladder, NE, PAC, } \\
\text { cholangio, SCLC, SQS }\end{array}$ & $\begin{array}{l}\text { HCC, HNSCC, NSCLC, cervix, ES, renal, } \\
\text { NPC }\end{array}$ & ERBB2 \\
\hline $\operatorname{dim}(18 q)$ & Gastric, ovary, CRC, HNSCC, PAC, SQS & $\begin{array}{l}\text { HCC, NSCLC, cervix, renal, bladder, } \\
\text { cholangio }\end{array}$ & DCC, SMAD4 \\
\hline $\operatorname{enh}(19 q)$ & NE, SCLC & Breast, CRC, PAC, vulva & AKT2, BAX \\
\hline $\operatorname{enh}(20 q)$ & $\begin{array}{l}\text { Gastric, CRC, thyroid, bladder, NE, } \\
\text { PAC, cholangio }\end{array}$ & $\begin{array}{l}\text { Breast, HCC, cervix, ES, renal, MEL, SCLC, } \\
\text { vulva }\end{array}$ & STKI5/AuroraA \\
\hline
\end{tabular}

Please refer to table I for abbreviations. * "most frequent" lists entities in which the aberration belongs to the 3 most frequent imbalances of the specified quality (enh = gain, dim = loss; bold if most frequent change in entity). Entities are sorted according to the total number of included cases. Chromosomal regions Ip, 2I, 22, $\mathrm{X}$ and $\mathrm{Y}$ were omitted due to differences in reporting (e.g. exclusion of regions prone to errors in chromosomal $\mathrm{CGH}$ analysis). ** Listed are some examples of genes with oncogene (for gain regions) or tumor suppressor (for loss regions) function. However, a large number of possible target genes as well as structural features may exist for each region.

Ovarian carcinoma (449 cases)

Gains: 8q24 (43.7\%), 3q26 (38.1\%), 1q32 (25.3\%), $12 \mathrm{p} 12(19.2 \%), 2,5 \mathrm{p}, 6 \mathrm{p}, 7 \mathrm{q}, 11(\mathrm{q} 13)$

Losses: 5q14 (25.2\%), 4q (26.3\%), 18q21 (19.8\%), 17p (19.6\%), 8p (19.4\%), 6q, 9q, 13q, 16q, X
Gains on 12p have been discussed as early event in ovarian carcinomas with frequent occurrence in borderline tumors [50], and several other changes have been linked to advanced carcinomas [51]. Overall, advanced stage tumors showed a higher grade of chromosomal instability. 
Colorectal adenocarcinoma (430 cases)

Gains: 20q13 (53\%), 13q (38.6\%), 8q24 (37.2\%), 7(p) (35.6\%), X(q21), 1q, 5p, 12(p), 19

Losses: 18q(22) (47.4\%), 8p(22) (37.9\%), 17p12 (27\%), 4 (up to $23.7 \%$ ), $14,15,22$

In colorectal carcinoma, gains on 8q23q24 [52] have been associated with lymph-node positivity. In a recent study, gains on $20 \mathrm{q}$ as well as KRAS mutations could bee shown to precede aneuploidy [53]. An overview is provided in [54].

Hepatocellular adenocarcinoma (HCC; 37 I cases)

Gains: 1q23q31 (46.6\%), 8q24 (44.8\%), 6p21 (22.4\%), $17 \mathrm{q}(21.8 \%), 5,7,20$

Losses: $4 \mathrm{q}$ (up to 31.3\%), 8p(21) (31.3\%), 13q21 (28.3\%), 16q(21) (25.9\%), 17p13 (25.3\%), 1p, 6q, 14, 18

Losses of 8p have been shown to distinguish HCC from other liver malignancies [55]. Also, losses on $4 \mathrm{q}$ and $13 \mathrm{q}$ were associated with poor differentiation [56]. An overview of genomic changes in HCC with discussion of putative target genes is provided in [57].

Head-neck squamous cell carcinoma, excluding nasopharyngeal ca. (HNSCC; 339 cases)

Gains: 3q26 (59.2\%), 8q24 (40.8\%), $11 \mathrm{q} 13$ (31.9\%, many specific high-level), 5p (26.5\%), Xq, 1q, 7q(21), $12 \mathrm{p}, 17$

Losses: 3p (30.1\%), 18q(22) (22.4\%), 9p (22.4\%), 11q24 $(19.2 \%), 4,5 q, 8 p, 13$

Genomic imbalances in HNSCC are in line with other squamous cell carcinomas $(-3 p,+3 q,+5 p)$. The high rate of amplifications at $11 \mathrm{p} 13$ has been shown to involve the cyclin D1 (CCND1) locus and to be accompanied by high expression of the gene [58].

Thyroid carcinoma (3 / 4 cases)

Gains: 5(p), 7, 20(q)

Losses: 13q, 22, 1p

Although a number of highly aberrant cases was included (see outliers in box plot, Figure 1), thyroid carcinomas, including all variants, showed an overall the lowest level of chromosomal imbalances. The subset included a large study in post-Chernobyl tumors in children, for which imbalances could be found only in $30 \%$ of tumors [59]. Interestingly, anaplastic carcinomas had a low median number but high variability. Although not mapping to regions with frequent genomic gains in the the included cases, previous reports have shown e.g. amplification of PRKCE on 2p21 [60] and FGF3 [61].

Non-small cell lung carcinomas (NSCLC; 3 I 4 cases)

Gains: 5p (52.8\%), 3q26 (39.4\%), 8q24 (35.4\%), 1q(21)

$(28.4 \%), 3,6 \mathrm{p}, 11 \mathrm{q} 13,12 \mathrm{p}, 17 \mathrm{q}, 18 \mathrm{p}$

Losses: 3p (31.9\%), 4(q) (26.4\%), 5q (26\%), 13q21 $(25.6 \%), 8 \mathrm{p}(21)(24 \%), 9$ (up to $20.5 \%), 17 \mathrm{p}(16.5 \%)$, $1 \mathrm{p}, 6 \mathrm{q}, 10,18 \mathrm{q}$

NSCLC is a histologically heterogeneous group, consisting of squamous (SCC) and non-squamous (NSCC) cases. Imbalances have been shown to be partially shared between the groups, with differences in the frequency of some regional involvements [62].

\section{Cervix carcinoma (226 cases)}

Gains: 3q26qter (53.6\%), 1q (up to $28.3 \%$ ), 5p (27.4\%), $8 q 24(20.3 \%), 6 p, 9(q), 17 q, 20 q, X$

Losses: $2 q 36(30.1 \%$ ), 3p (up to $25.2 \%$ ), 4 (up to $23.5 \%$ ), $11 \mathrm{q} 23 \mathrm{q} 24$ (23\%), 6q, 13q, 17p, 18

The number of chromosomal changes may be influenced by occurrence and type of HPV infection. However, in a large study no correlation between single imbalances and clinical parameters could be identified [63]. Losses of the telomeric region of $2 q$ were frequent and rarely found in other entities.

\section{Esophagus carcinoma (209 cases)}

Gains: 3q(26) (53.2\%), 8q24 (49.8\%), 7p (34\%), $20 \mathrm{q} 13$ (32.6), 1q (29.7\%), 7q21 (29.7\%), 5p (28.7\%), Xq (23.4\%), 6p12 (22.9\%), 12p (22.5\%), 11q13 (22.1\%), $17 \mathrm{q} 21(21.6 \%), 2(\mathrm{q}), 9 \mathrm{q}$

Losses: $3 p$ (up to $37.3 \%$ ), $18 \mathrm{q}(37.3 \%), 4$ (up to $33 \%$ ), $5 q(21)(29.2 \%), 9 p(26.3 \%), 8 p(23.4 \%), 13 q$ (up to $23 \%), 1 \mathrm{p}(22.5 \%), 19 \mathrm{q}(2 \%), 17 \mathrm{p}(20.1 \%), 10,11, \mathrm{Xp}$

Esophagus carcinomas showed an overall high "background" of gains and losses, with the 2nd highest number of imbalances per case. This group consists of cases with squamous cell as well as adenocarcinoma or intestinal adeno-ca. histology. Besides specific de-regulation of oncogenes, an effect of the massive genomic changes on chromatin structure has been discussed previously [64].

Renal carcinoma (RCC, 195 cases)

Gains: 7 (up to 33.4\%), 5q(31) (32.8\%), 8q23q24 $(19.5 \%$ ), 20 (up to $18.5 \%$ ), $17 q$ (up to $17.4 \%$ ), 1qter (13.1\%), 3q, 12, 16 
Losses: $3 p$ (up to $43.1 \%$ ), $14 q$ (up to $26.2 \%$ ), 6q (21\%), 1 p (up to $20 \%), 9$ (20\%), 8p (19.5\%), 13q (19.5\%), 17p (19\%), 18q (18\%), 2, 4, 10

Gains of $5 \mathrm{q}$ are a rare occurrence in other carcinomas, and have been identified in papillary as well as non-papillary cases [65]. An overview of accumulated karyotype data was given in 2004 [66], proposing different cytogenetic pathways and associating papillary RCC with a hyperdiploid karyotype pattern.

Nasopharynx carcinoma (NPC; 177 cases)

Gains: $12 \mathrm{p}$ (up to 33.9\%), 1q (24.3\%), 3q (22\%), $8 q 22 q 23(19.5 \%), 18 p(17 \%), 11 q 13(12.4 \%), 2(q)$, $4(q), 6(q), 17 q$

Losses: 16q (29.9\%), 14q24 (27.7\%), 11q23 (24.3\%), 1pter (23.7\%; difficult region), 9, 13q31, 17p, 19p

In contrast to some other carcinoma entities, the maximum of gains mapped clearly proximal to the $c$-myc region. A meta-analysis of CGH data in NPC was recently provided by Li et al. [67]. In concordance with the low number of NPC cases with 8 p deletion, the oncogenetically relevant DLC1 on 8p22 has been reported to be inactivated by methylation rather than copy number change [68].

\section{Bladder carcinoma ( 169 cases)}

Gains: 20q (21.3\%), 8q (20.7\%), 17q (20.7\%), 11q13 (19.5\%), 1q21 (17.8\%), 5p, 6p, 7, 10p

Losses: 9 (26\%), 13q21 (17.8\%), 4q (up to $14.2 \%), 11 p$ (14.2\%), 5q (14.6\%), 2q32, 8p, 6q, 18q, X, 17p

While some of the imbalances (e.g. 8q, 17q and 20q gain, 11 q13 gain/amplification) were frequent in other entities, losses on chromosome 9 were exceptionally high in transitional cell carcinoma ( 115 cases). In contrast to other squamous cell carcinomas, gains on 3 q were rare ( 3 of 40 bladder SCC). In one study included in the data, some differences between histological and etiological subtypes of bladder carcinomas were presented [69].

\section{Neuroendocrine carcinoma and carcinoid (I 38 cases)}

Gains: 19 (26.1\%), 20 (up to $18.1 \%$ ), 17q (up to $17.4 \%$ ), $5 \mathrm{p}(15.9 \%)$

Losses: 11q22q25 (20.3\%), 13q21 (18.1\%), 3p (up to $15.5 \%), 6 q 22$ (13\%), 10q25q26 (13\%)

Possibly due to the heterogeneity of this group, a diffuse background of whole chromosome gains was observed. The genetics of neuroendocrine tumors was recently reviewed with consideration for inherited syndromes as well as molecular cytogenetic results [70].

Malignant melanocytic neoplasias (99 cases)

Gains: 8q(21) (36.3\%), 6p (32.3\%), 1q (22\%), 7, 20q, $11 \mathrm{q} 13$

Losses: $6 \mathrm{q}(24)(29.3 \%), 10$ (q22) (22.2\%), 3 (up to $21.2 \%), 9 p(21.2 \%), 13 q, 1 p, 11 q 23 q 24$

In contrast to most epithelial malignancies, gains on $6 \mathrm{p}$ can be found in a large proportion of malignant melanomas. Above background losses on $10 \mathrm{q}$ are found in few other entities, too. Similar to other entities gains on $8 \mathrm{q}$, $1 \mathrm{q}, 20 \mathrm{q}$ and chromosome 7 can be observed. A comprehensive overview about molecular-cytogenetic techniques in the analysis of melanocytic lesions was given by Bauer and Bastian [71].

\section{Pancreas adenocarinoma (88 cases)}

Gains: $20 \mathrm{q}$ (up to $30.7 \%$ ), $8 \mathrm{q}(23)(26.2 \%$ ), $17 \mathrm{q}$ (up to $21.6 \%), 12 \mathrm{p} 11(19.3 \%), 7 \mathrm{p}(18.2 \%), 3 \mathrm{q}$ (up to $17.1 \%)$, $5 \mathrm{p}, 11(\mathrm{q} 13), 14,15 \mathrm{qter}, 16,19 \mathrm{q}$

Losses: $18 \mathrm{q}(35.2 \%), 9 \mathrm{p}(23)(29.6 \%), 13 q(18.2 \%), 3 p$ (up to $17.1 \%), 6 q(21)(17.1 \%), 8 p(17.1 \%), 17 \mathrm{p} 13$ $(15.9 \%), 4,15 q, 10 q, 12 q$

This subset only includes pancreas adenoocarcinomas, omitting endocrine tumors.

High level copy number amplifications have been shown e.g. for ERBB2 (17q12) and EGFR (7p12). Interestingly, the maximum for gains on $8 \mathrm{q}(8 \mathrm{q} 22)$ is proximal to the $c$ $m y c$ region. This fact was also mentioned in a recent overview of genomic screening results in pancreas ca. [72].

\section{Cholangio-carcinomas (intra- and extrahepatic; 63 cases)}

Gains: $8 \mathrm{q} 22$ (42.9\%), 17q (up to $39.7 \%), 20 \mathrm{q}(34.9 \%)$, $11 \mathrm{q} 13(23.8 \%), 15 \mathrm{q}$ (up to $23.8 \%), 3 \mathrm{q}(26)(20.7 \%), 7 \mathrm{p}$ (up to $20.7 \%$ ), $13 q$ (up to $20.7 \%$ ), 5p (up to $19.1 \%$ ), 1q, $6 \mathrm{p}, 12 \mathrm{q} 23 \mathrm{q} 24$

Losses: 1p34p36 (up to 22.2\%), 4q (up to 20.6\%), 17p (19.1\%), 5q(14), 6q, 13q, 18qter, $X$

Gains on $15 q$ were reported in up to $36 \%$ (in a study of Korean intrahepatic cholangio-ca. [73]), but rarely seen in other entities.

Small-cell lung carcinoma (SCLC; 63 cases)

Gains: 19 (up to $44.4 \%$ ), $3 q$ (up to $41.3 \%$ ), $17 q 23$ (41.3\%), 1p31p34 (38.2\%), 8q(23) (36.5\%), 20q (up to $30.2 \%), 14 q 31 \mathrm{q} 32(26 \%), 1 \mathrm{q}$ (up to $25.4 \%), 9 \mathrm{q} 31 \mathrm{q} 34$, $6 \mathrm{p}, 13 \mathrm{q} 32$ 
Losses: $3 p$ (84.1\%), 4 (up to $74.1 \%$ on 4 qter), $13 q(14)$ (69.8\%), 10(q) (41.3\%), 17p13 (33.3\%), 2(q23q24) (31.8\%), 8p (25.4\%), 9, 11, 15, 6q, 16q

SCLC had the highest number of chromosomal imbalances (median 12 involved chromosomes per case). Also, some of the imbalances constituted the overall highest fractional aberrations in all datasets (e.g. $>80 \%$ losses on $3 p)$, as well as very frequent losses on $4 q, 13 q$ and $10 q$. Although frequent gains on $7 \mathrm{p}$ had been reported from array CGH of SCLC cell lines [74], this region was rarely involved in the mostly clinical specimen analyzed by chromosomal CGH.

\section{Endometrial carcinoma (56 cases)}

Gains: 1q (50\%), 8q(22) (39.3\%), 3q26 (14.3\%), 10 (up to $14.3 \%$ )

Losses: 10q (12.5\%), 13q (10.7\%), 14q, 9q

As in e.g. nasopharynx ca., SCLC and pancreas ca., the maximum of $8 \mathrm{q}$ gains was proximal of $8 \mathrm{q} 24$. Endometrial ca. show an exceptional high rate of gains on 1q, which were also the most frequent change in a series of 98 cases not available for inclusion here [75]. Interestingly, chromosome 10 was also frequently involved (both gains and losses).

\section{Carcinomas of the vulva (53 cases)}

Gains: 3q (45.7\%), 8q(23) (34\%), 1 (up to $28.3 \%$ ), $5 p(15)(26.4 \%), 20 q(24.5 \%), 9 q(20.8 \%), 6,7,12,14$, $19, \mathrm{X}$

Losses: 3p (22.6\%), 4p (22.6\%), 11q23q25 (20.8\%), $13 q 14(13.2 \%), 8 p, 10, \mathrm{X}$

Vulvar carcinomas showed an imbalance pattern characteristic for squamous cell neoplasias, with a high rate of gains on $8 \mathrm{q} 23$ and especially $3 \mathrm{q}$. As in cervix ca., the most frequent changes could not be related to HPV status [76].

Squamous cell carcinomas of the skin (52 cases)

Gains: 3q (11.5\%), 17q (11.5\%), Xq (9.6\%), 1q, 8q, 14q

Lossses: 9p21 (19.2\%), 3p (13.5\%), 18q (13.5\%), 17p $(9.6 \%)$

While containing many cases of borderline malignant behaviour, squamous skin neoplasias had the overall lowest aberration frequencies (median 0 ). This group did not include the pre-malignant keratoacanthomas, for which a frequent gain of $11 \mathrm{q}$ and cyclin D1 overexpression had been shown [77].

\section{Disease-specific Involvement of most frequently aberrant chromosomes and relationship of overall aberration profiles}

Several chromosomal hot spot regions showed a pronounced disease related variation. The most prominent regions scoring high in specific entities are listed in Table 2 . To reduce sampling bias (e.g. entity specific inclusion of a high proportion of early stage cases) top-scoring aberrations were defined as the most frequent gains or losses in each entity. Some additional imbalances which occured only in few entities at high levels are listed in Table 3. In an attempt to identify the relation of single case aberration profiles, a cluster analysis of all 5043 informative cases was performed. For that purpose, a band specific matrix with 86 bands resolution was generated, of which the 55 intervals most frequently involved in imbalances were selected (top-scorers in one or more entities, ref. Tables 2 and 3; e.g. "8q2"). Hierarchical cluster analysis revealed the complexity of the case-specific aberration patterns, and was able to visualize concordance of imbalance patterns and disease categories in small groups of cases (Figure 3).

To reduce the complexity of the data and simplify the detection of similarities in the aberration patterns of different entities, region specific aberration frequencies of all entities were clustered. For each of the 55 selected intervals, the sum of gains - losses was calculated, resulting in a $22 \times 55$ matrix (entities $\times$ intervals). During hierarchical cluster analysis, values were normalized over each entity's intervals, to account for differences in genomic complexity. Figure 4 depicts the result of the cluster analysis, in which overall similarities and differences in the different entities become apparent.

Differences in aberration profiles in some instances will reflect the general histological type, which is substantiated by the close relation of overall profiles e.g. from clinicopathological groups containing squamous cell carcinoma cases (group NSCLC/esophagus/HNSCC/cervical/vulva in Figure 4). To evaluate this effect, the most frequent histopathological entities (adenoca., squamous cell ca., hepatocellular ca., ductal breast ca., transitional cell ca., intestinal adenoca.) were selected. Additionally, adenocarcinomas of the prostate were put in a separate group, due to the previous observation of specificities in the imbalance profile (e.g. overall lack of 1q gains). Clustering was performed analogous to the method described above. Figure 5 visualizes the clustering of those histopathological entities.

In comparing the most frequent imbalances for their occurrence in different entities, some general observations stood out. Gains involving the terminal part of $8 \mathrm{q}$ were ubiquitously found, and often belonged to the most fre- 


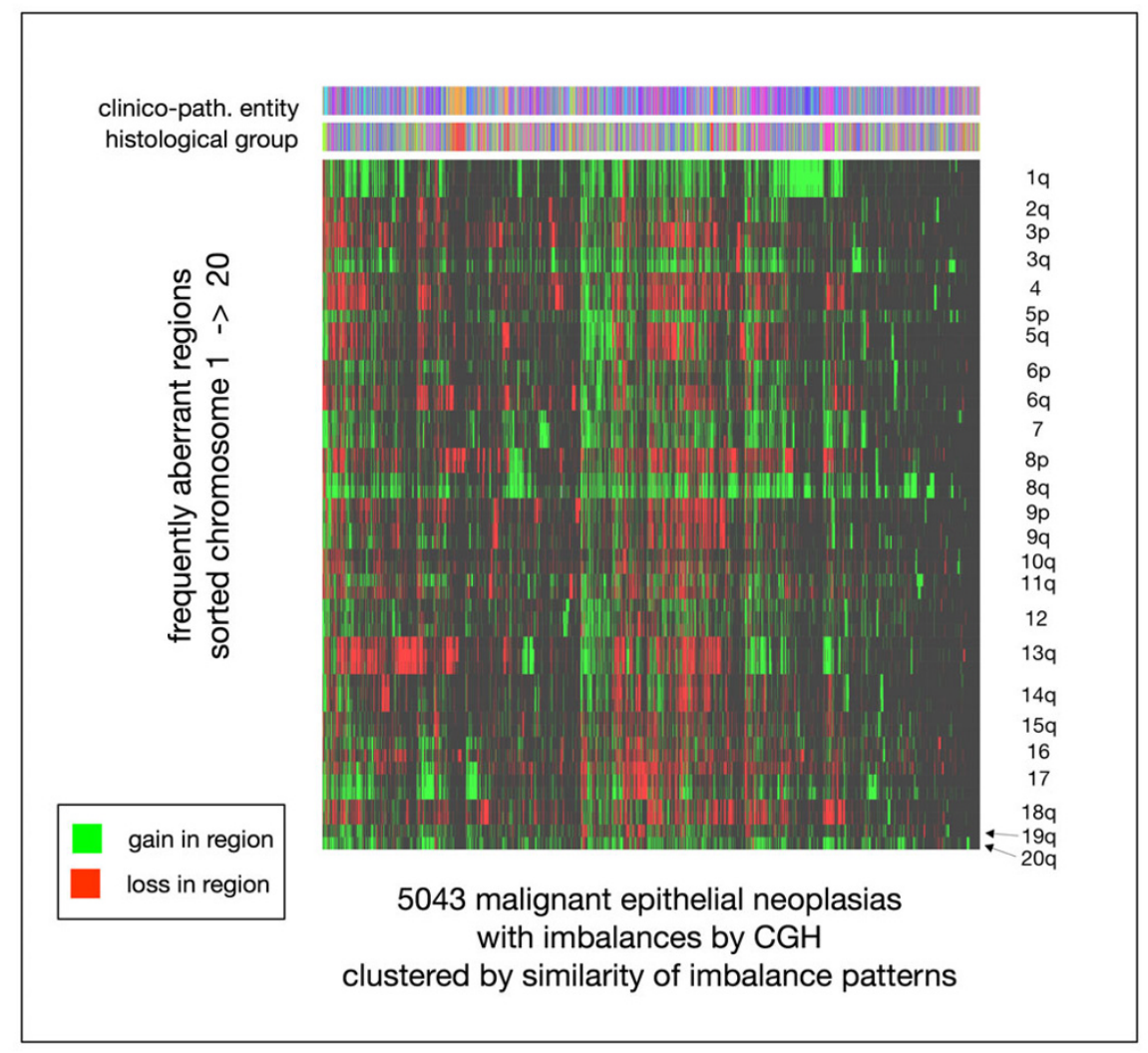

\section{Figure 3}

Clustering of 5043 malignant epithelial neoplasias by the pattern of gains and losses, using regions previously defined as highly aberrant in one or several entities (ref. tables $2+3$ ). For each case (x-axis), gains (green) and losses (red) are indicated for the corresponding chromosomal regions ( 55 selected bands; $y$-axis). The color bar codes on top indicate the cases' assignments to the different clinico-pathological entities and histological groups (color code is provided in the additional file $\mathrm{I}$ ).

quent imbalances in the respective entities. Hovever, they were rarely detected in neuroendocrine carcinomas and thyroid neoplasias. Interestingly, in some entities the maximum of detected abnormalities mapped proximal of 8 q24 (e.g. 8q21 in melanocytic NPL and 8q22 in NPC and cholangio ca.). How much this reflects a true difference in regional involvement, and therefore may point to differential target gene involvement has to be left open here.
Gains on 1q with maxima on 1q2 were also frequent, and were the most frequent changes in breast, hepatocellular and endometrial carcinomas. However, 1q gains were comparatively infrequent in carcinomas of the prostate and bile ducts as well as in renal and colorectal ca. Overall gains on 3q26q27 combined with losses on 3p were characteristic for squamous cell carcinomas and SCLC, with $3 q$ gains also being frequent in ovarial ca. and other entities.

Table 3: Selected imbalances with high penetrance limited to one or few entities

\begin{tabular}{|c|c|c|}
\hline Imbalance & Occurrence & Comment \\
\hline $\operatorname{dim}(2 q 22 q 31)$ & SCLC (up to $31.8 \%$ ) & $\begin{array}{l}\text { Profile appears region-specific; however, SCLC cases have very rich imbalance } \\
\text { pattern with more frequent changes }\end{array}$ \\
\hline $\operatorname{dim}(2 q 33 q 37)$ & Cervix (up to $30.1 \%$ ) & $\begin{array}{l}\text { Specific terminal } 2 q \text { deletions are else only found in low frequency in NSCLC and } \\
\text { bladder lesions }\end{array}$ \\
\hline $\operatorname{enh}(5 q 2$ l q35) & RCC (up to $32.8 \%$ ) & $\begin{array}{l}\text { Specific regional } 5 q \text { gains are near exclusive for renal carcinomas, and are here } \\
\text { part of whole chromosomal changes }(20 \%) \text { or limited to the region }\end{array}$ \\
\hline $\operatorname{dim}(10 q)$ & $\begin{array}{l}\text { SCLC (up to } 41.3 \% \text { ), melanocytic, } \\
\text { endometrial }\end{array}$ & Rare as specific changes above "background" \\
\hline $\operatorname{enh}(13 q)$ & CRC (up to $38.6 \%$ ), gastric & $\begin{array}{l}13 q \text { gains are rare except in } C R C \text {, esp. compared to the frequent losses in the } \\
\text { region }\end{array}$ \\
\hline
\end{tabular}




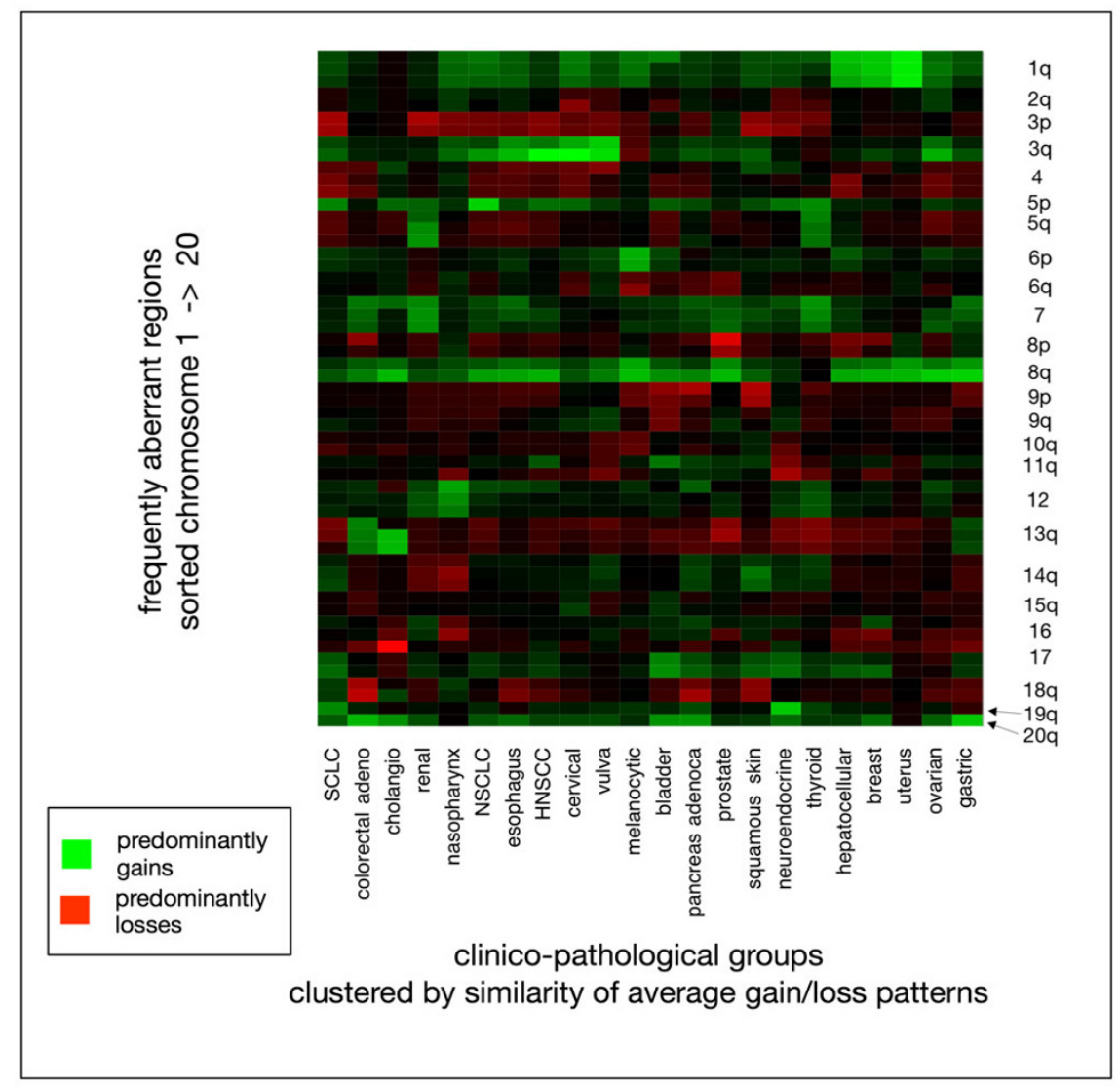

\section{Figure 4}

Clustering of carcinoma entities by their overall imbalance pattern. For each of the selected chromosomal regions, aberrations were summarized (percent gain - percent loss). After normalization of all regions over the respective entity, the color intensities represent the relative contribution of regional gains and losses to the overall aberration patterns.

While $5 p$ gains were found in various entities, gains on $5 q$ were frequent only in ca. of thyroid and kidney, as were gains on chromosome 12 . Overall, $13 \mathrm{q}$ losses could be detected in most entities. In contrast, 13q gains were predominant in cholangio ca. and also frequent in colorectal and gastric carcinomas.

Region specific gains involving $11 \mathrm{q} 13$ were found in a number of entities (bladder ca., HNSCC, pancreas, prostate, skin, ovary, gastric, NSCLC). Interestingly, of the overall 692 cases with gain on 11q13,18\% had a loss of the telomer of $11 \mathrm{q}$ by CGH (Figure 6). Since a strong selective pressure for such a switch in aberration quality in linked regions can be suspected, this observation may point towards targeting of both genes with oncogene and tumor suppressor functions on $11 \mathrm{q}$ in these tumors.

When comparing overall aberration patterns, entities containing squamous cell carcinoma cases (HNSCC, NSCLC, cervix and vulva ca., esophagus ca.) appeared related, with a common pattern offrequent losses on 3p, gains on 3q, $8 \mathrm{q}$ and varying gains on $1 \mathrm{q}$ and $5 \mathrm{p}$. NPC showed a slightly diverging pattern, with predominant $12 p$ gains and $14 \mathrm{q}$ losses in addition to slightly lower levels of those imbalances.

Interestingly, in both unselected renal carcinomas as thyroid neoplasias, the average imbalance profiles included frequent gains on chromosomes 5, 7 and 12, while lacking the dominance of gains $1 \mathrm{q}$ and $8 \mathrm{q}$ found in most other entities.

Apart from these observations, one should refer to the accompanying figures for a general comparison of patterns in different clinico-pathological groups. Also, the use of the Progenetix website tools is encouraged.

\section{Conclusion}

This study attempted an overview of chromosomal imbalance profiles in epithelial neoplasias, based on a large col- 


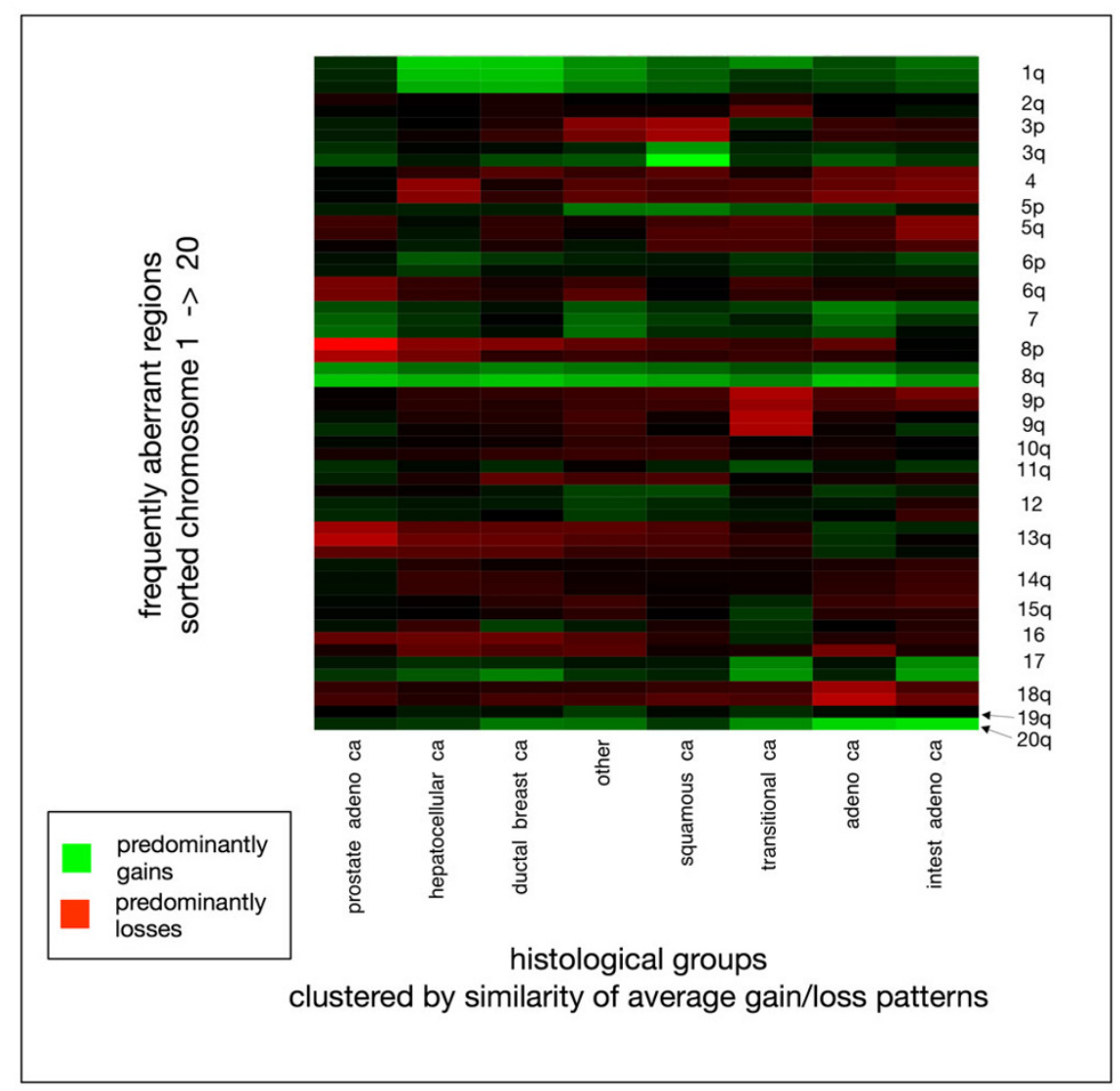

\section{Figure 5}

Clustering of different histologies in carcinomas by their overall imbalance pattern. Here, the most frequent histological types were automatically grouped for their overall imbalance profiles. Since considerable differences had been found for adenocarcinoma cases from the prostate (most notably lack of Iq gains), this group was separeted from the overall adenocarcinoma group.

lection of case-specific chromosomal imbalance data from published chromosomal CGH experiments. The most striking observations were the high frequency of a limited set of changes $(+1 q,+3 q,+7,+8 q,-13 q,-17 p$, $18 \mathrm{q},+20 \mathrm{q} \ldots)$, of which different subsets occurred in most entities. The iterative involvement of certain genomic regions in either gains or losses is a strong argument for the non-random incorporation of these changes into the tumor cell genomes, with common as well as disease specific changes becoming apparent. One may speculate that the recurring combination of a limited set of imbalance hot-spots is concordant with the multistep process of cancer development [78], and that these regions point towards preferential oncogenetic targets. For a detailed discussion of the region-specific changes and patterns related to single disease entities, only examples could be given in the context of this article. The existing literature should be considered for additional information.
This descriptive analysis of local genomic imbalance frequencies cannot be able to address some important questions, e.g. regarding the biological significance of the observed changes. Although certain genomic copy number amplifications and segmental deletions have been shown to involve oncogenetically relevant genes in various malignancies (see Table 2 and for reference e.g. [79-82]), some of the recurring genomic imbalances might be as well pure epi-phenomena of defects in the molecular maintenance of the genome. In respect to the limited spatial resolution and phenomenological nature of the data, the discussion and validation of specific target genes should be left to meticulously crafted molecularbiological experiments.

Cluster analysis of case specific chromosomal CGH data has been used previously to identify subsets of cases in single clinico-pathological entities [45,83,84]. Current methodology appears more suited for limited data sets, while new algorithms have to be developed for automatic 


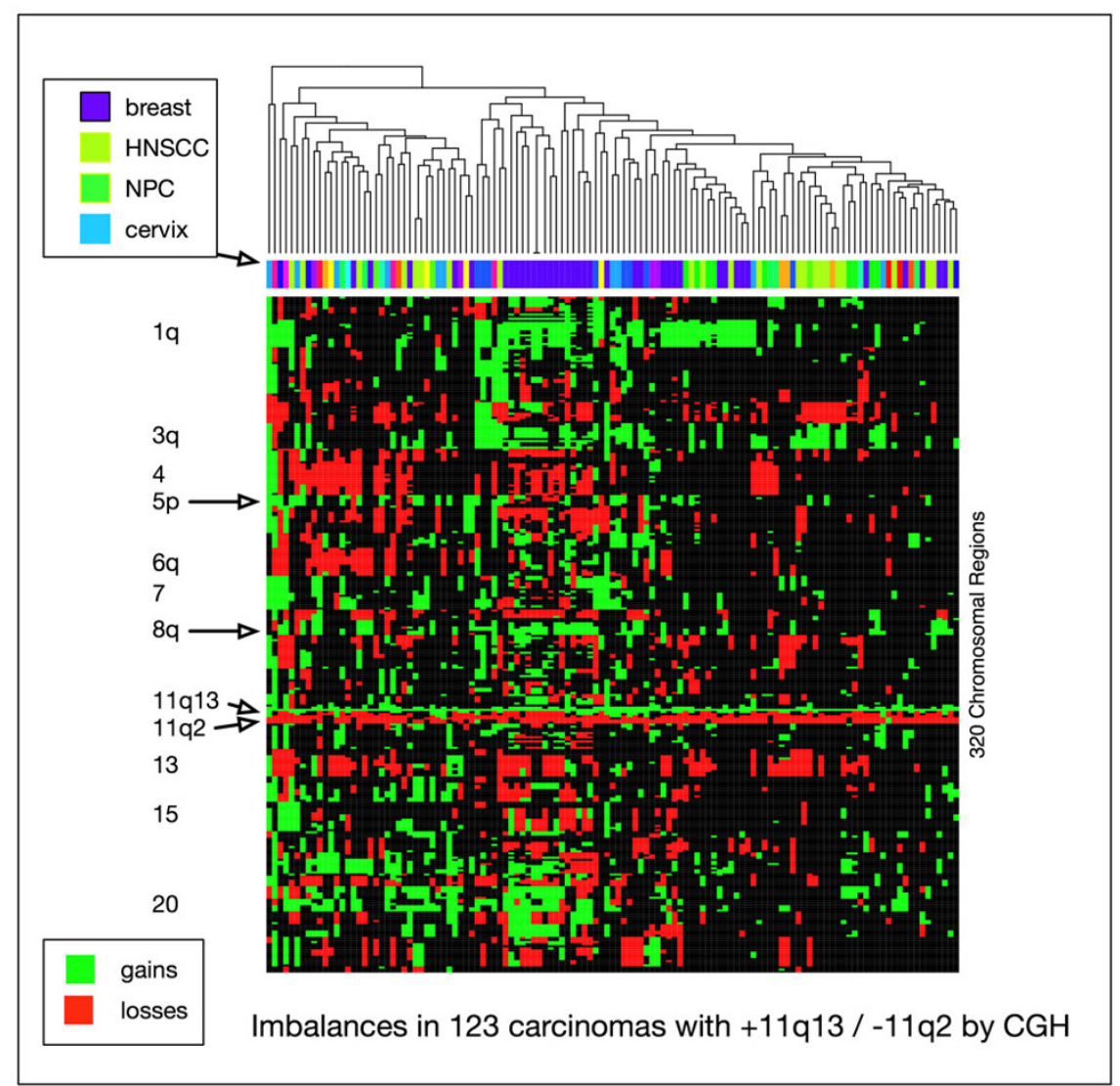

Figure 6

Visualization of single case aberration patterns in 123 carcinomas with gain on I I qI 3 and concomitant proximal loss. Cases are clustered according to their imbalance patterns (gain/loss status, 320 bands resolution).

subgroup detection from large, heterogeneous series of CGH data $[85,86]$. This is especially challenging regarding the variant background of chromosomal copy number changes found in certain tumor types, which may be based on aberrant expression of regulatory genes [41]. Since genomic copy number changes constitute only one of many mechanisms leading to aberrant gene regulation, the deduction of oncogenetic pathways from CGH data will remain a challenging project. However, the combination of existing large-scale data collections and current high resolution screening techniques should provide additional pieces for these puzzles. For that purpose, the Progenetix data collection is open for inclusion into data mining projects.

\section{Competing interests}

The author(s) declare that they have no competing interests.

\section{Authors' contributions}

MB designed the study, assembled the data collection, performed the data analysis and wrote the manuscript.

\section{Additional material}

\section{Additional file 1}

Supplementary figures. The file contains imbalance histograms for each of the different clinico-pathological entities and additional box plots depicting the number of aberrant chromosomes per entity and histological subset.

Click here for file

[http://www.biomedcentral.com/content/supplementary/14712407-7-226-S1.pdf]

\section{Acknowledgements}

I am indebted to the authors of a number of articles, who provided the data for the database that otherwise would not have been accessible. Progenetix database contributors are listed on the project's website [25]. During a part 
of the project, the author has been supported through a grant from the Claussen-Simon-Stiftung.

\section{References}

I. Patau K: The identification of individual chromosomes, especially in man. Am J Hum Genet 1960, I 2:250-276.

2. Crossen PE: Giemsa banding patterns of human chromosomes. Clin Genet 1972, 3:169-179.

3. Speicher MR, Gwyn Ballard S, Ward DC: Karyotyping human chromosomes by combinatorial multi-fluor FISH. Nat Genet 1996, I 2:368-375

4. Veldman T, Vignon C, Schrock E, Rowley JD, Ried T: Hidden chromosome abnormalities in haematological malignancies detected by multicolour spectral karyotyping. Nat Genet 1997, | 5:406-410.

5. Cremer T, Lichter P, Borden J, Ward DC, Manuelidis L: Detection of chromosome aberrations in metaphase and interphase tumor cells by in situ hybridization using chromosome-specific library probes. Hum Genet 1988, 80:235-246.

6. Lichter P, Cremer T, Borden J, Manuelidis L, Ward DC: Delineation of individual human chromosomes in metaphase and interphase cells by in situ suppression hybridization using recombinant DNA libraries. Hum Genet 1988, 80:224-234.

7. Kallioniemi A, Kallioniemi OP, Sudar D, Rutovitz D, Gray JW, Waldman F, Pinkel $D$ : Comparative genomic hybridization for molecular cytogenetic analysis of solid tumors. Science 1992, 5083:818-821.

8. Joos S, Scherthan H, Speicher MR, Schlegel J, Cremer T, Lichter P: Detection of amplified DNA sequences by reverse chromosome painting using genomic tumor DNA as probe. Hum Genet 1993, 90(6):584-589.

9. Bentz M, Plesch A, Stilgenbauer S, Dohner H, Lichter P: Minimal sizes of deletions detected by comparative genomic hybridization. Genes Chromosomes Cancer 1998, 2:172-175

10. Solinas-Toldo S, Lampel S, Stilgenbauer S, Nickolenko J, Benner A, Dohner H, Cremer T, Lichter P: Matrix-based comparative genomic hybridization: biochips to screen for genomic imbalances. Genes Chromosomes Cancer 1997, 4:399-407.

II. Pinkel D, Segraves R, Sudar D, Clark S, Poole I, Kowbel D, Collins C, Kuo WL, Chen C, Zhai Y, Dairkee SH, Ljung BM, Gray JW, Albertson DG: High resolution analysis of DNA copy number variation using comparative genomic hybridization to microarrays. Nat Genet 1998, 2:207-2। I.

12. Pollack JR, Perou CM, Alizadeh AA, Eisen MB, Pergamenschikov A, Williams CF, Jeffrey SS, Botstein D, Brown PO: Genome-wide analysis of DNA copy-number changes using cDNA microarrays. Nat Genet 1999, I:41-46.

13. Nowell PC, Hungerford DA: A minute chromosome in chronic granulocytic leukemia. Science 1960, I32: I497.

14. Rowley JD: Letter: A new consistent chromosomal abnormality in chronic myelogenous leukaemia identified by quinacrine fluorescence and Giemsa staining. Nature 1973, 5405:290-293

15. Manolov G, Manolova Y: Marker band in one chromosome I4 from Burkitt lymphomas. Nature 1972, 237:33-34.

16. Mrozek K, Heerema NA, Bloomfield CD: Cytogenetics in acute leukemia. Blood Rev 2004, I 8: I I5-I36.

17. Mitelman Database of Chromosome Aberrations in Cancer [http://cgap.nci.nih.gov/Chromosomes/Mitelman]

18. Speicher MR, du Manoir S, Schrock E, Holtgreve-Grez H, Schoell B, Lengauer C, Cremer T, Ried T: Molecular cytogenetic analysis of formalin-fixed, paraffin-embedded solid tumors by comparative genomic hybridization after universal DNA-amplification. Hum Mol Genet 1993, I I:1907-1914.

19. Knuutila S, Bjorkqvist AM, Autio K, Tarkkanen M, Wolf M, Monni O, Szymanska J, Larramendy ML, Tapper J, Pere H, El-Rifai W, Hemmer $S$, Wasenius VM, Vidgren $V$, Zhu Y: DNA copy number amplifications in human neoplasms: review of comparative genomic hybridization studies. Am J Pathol 1998, I 52: I I 07- I I 23.

20. Knuutila S, Aalto Y, Autio K, Bjorkqvist AM, El-Rifai W, Hemmer S, Huhta T, Kettunen E, Kiuru-Kuhlefelt S, Larramendy ML, Lushnikova T, Monni O, Pere H, Tapper J, Tarkkanen M, Varis A, Wasenius VM, Wolf $M$, Zhu $Y$ : DNA copy number losses in human neoplasms. Am J Pathol 1999, I 55:683-694.
21. Gebhart E, Liehr T: Patterns of genomic imbalances in human solid tumors (Review). Int J Oncol 2000, I 6:383-399.

22. Gebhart E: Genomic imbalances in human leukemia and lymphoma detected by comparative genomic hybridization (Review). Int J Oncol 2005, 27:593-606.

23. Struski S, Doco-Fenzy M, Cornillet-Lefebvre P: Compilation of published comparative genomic hybridization studies. Cancer Genet Cytogenet 2002, I 35:63-90.

24. Myllykangas S, Himberg J, Bohling T, Nagy B, Hollmen J, Knuutila S DNA copy number amplification profiling of human neoplasms. Oncogene 2006, 25:7324-7332.

25. Progenetix - cytogenetic abnormalities in human cancer [http://www.progenetix.net]

26. Baudis M, Cleary ML: Progenetix.net: an online repository for molecular cytogenetic aberration data. Bioinformatics 200I, I 2: 1228-1229.

27. Baudis M: Online database and bioinformatics toolbox to support data mining in cancer cytogenetics. Biotechniques 2006, 40(3):269-272.

28. Schwaenen C, Nessling M, Wessendorf S, Salvi T, Wrobel G, Radlwimmer B, Kestler HA, Haslinger C, Stilgenbauer S, Dohner H, Bentz $M$, Lichter $P$ : Automated array-based genomic profiling in chronic lymphocytic leukemia: development of a clinical tool and discovery of recurrent genomic alterations. Proc Natl Acad Sci USA 2004, 4: 1039-1044.

29. International Classification of Diseases for Oncology (ICDO), Edition. In World Health Organization Third edition. Edited by: Fritz A, Percy C, Jack A, Sobin LH, Parkin MD. Geneva; 2000.

30. Speicher MR, Schoell B, du Manoir S, Schrock E, Ried T, Cremer T, Storkel S, Kovacs A, Kovacs G: Specific loss of chromosomes I, $2,6,10,13,17$, and 21 in chromophobe renal cell carcinomas revealed by comparative genomic hybridization. Am J Pathol 1994, I45:356-364.

31. Wild P, Giedl J, Stoehr R, Junker K, Boehm S, van Oers J, Zwarthof E, Blaszyk H, Fine S, Humphrey P, Dehner L, Amin M, Epstein J, Hartmann A: Genomic aberrations are rare in urothelial neoplasms of patients 19 years or younger. J Pathol 2006.

32. Clausen OP, Aass HC, Beigi M, Purdie KJ, Proby CM, Brown VL, Mattingsdal M, Micci F, Kolvraa S, Bolund L, Deangelis PM: Are Keratoacanthomas Variants of Squamous Cell Carcinomas? A Comparison of Chromosomal Aberrations by Comparative Genomic Hybridization. J Invest Dermatol 2006.

33. van Beers EH, van Welsem T, Wessels LF, Li Y, Oldenburg RA, Devilee P, Cornelisse CJ, Verhoef S, Hogervorst FB, van't Veer LJ, Nederlof PM: Comparative genomic hybridization profiles in human BRCAI and BRCA2 breast tumors highlight differential sets of genomic aberrations. Cancer Res 2005, 65:822-827.

34. The Perl Directory at Perl.org [http://www.perl.org]

35. UCSC Genome Bioinformatics [http://genome.ucsc.edu]

36. Bioconductor - open source software for bioinformatics [http://www.bioconductor.org]

37. The R Project for Statistical Computing [http://www.rproject.org]

38. GD.pm Perl interface to GD graphics library [http:// stein.cshl.org/WWW/software/GD/]

39. GD open source code library for the dynamic creation of images [http://www.libgd.org]

40. Vos CB, ter Haar NT, Rosenberg C, Peterse JL, Cleton-Jansen AM, Cornelisse C], van de Vijver MJ: Genetic alterations on chromosome 16 and 17 are important features of ductal carcinoma in situ of the breast and are associated with histologic type. Br J Cancer 1999, 81:1410-1418.

41. Fridlyand J, Snijders AM, Ylstra B, Li H, Olshen A, Segraves R, Dairkee S, Tokuyasu T, Ljung BM, Jain AN, McLennan J, Ziegler J, Chin K, Devries S, Feiler H, Gray JW, Waldman F, Pinkel D, Albertson DG: Breast tumor copy number aberration phenotypes and genomic instability. BMC Cancer 2006, 6:96.

42. Aubele M, Auer G, Braselmann H, Nahrig J, Zitzelsberger H, Quintanilla-Martinez L, Smida J, Walch A, Hofler H, Werner M: Chromosomal imbalances are associated with metastasis-free survival in breast cancer patients. Anal Cell Pathol 2002, 24:77-87

43. Slamon DJ, Leyland-Jones B, Shak S, Fuchs H, Paton V, Bajamonde A, Fleming T, Eiermann W, Wolter J, Pegram M, Baselga J, Norton L: Use of chemotherapy plus a monoclonal antibody against 
HER2 for metastatic breast cancer that overexpresses HER2. N Engl J Med 200I, 344:783-792.

44. Barlund $M$, Tirkkonen $M$, Forozan $F$, Tanner MM, Kallioniemi $O$ Kallioniemi A: Increased copy number at I7q22-q24 by CGH in breast cancer is due to high-level amplification of two separate regions. Genes Chromosomes Cancer 1997, 20:372-376.

45. Mattfeldt T, Wolter H, Kemmerling R, Gottfried HW, Kestler HA Cluster analysis of comparative genomic hybridization (CGH) data using self-organizing maps: application to prostate carcinomas. Anal Cell Pathol 200I, 23(I):29-37.

46. Ribeiro FR, Jeronimo C, Henrique R, Fonseca D, Oliveira J, Lothe RA, Teixeira MR: 8q gain is an independent predictor of poor survival in diagnostic needle biopsies from prostate cancer suspects. Clin Cancer Res 2006, I 2:396I-3970.

47. Alers JC, Krijtenburg PJ, Vis AN, Hoedemaeker RF, Wildhagen MF, Hop WC, van Der Kwast TT, Schroder FH, Tanke HJ, van Dekken H: Molecular cytogenetic analysis of prostatic adenocarcinomas from screening studies: early cancers may contain aggressive genetic features. Am J Pathol 200I, I 58:399-406.

48. Sun J, Liu W, Adams TS, Sun J, Li X, Turner AR, Chang B, Kim JW, Zheng SL, Isaacs WB, Xu J: DNA copy number alterations in prostate cancers: a combined analysis of published CGH studies. Prostate 2007, 67:692-700.

49. van Grieken NC, Weiss MM, Meijer GA, Hermsen MA, Scholte GH, Lindeman J, Craanen ME, Bloemena E, Meuwissen SG, Baak JP, Kuipers EJ: Helicobacter pylori-related and -non-related gastric cancers do not differ with respect to chromosomal aberrations. J Pathol 2000, I 92:301-306.

50. Osterberg L, Akeson M, Levan K, Partheen K, Zetterqvist BM Brannstrom M, Horvath $G$ : Genetic alterations of serous borderline tumors of the ovary compared to stage I serous ovarian carcinomas. Cancer Genet Cytogenet 2006, I67:103-108.

5I. Partheen K, Levan K, Osterberg L, Helou K, Horvath G: Analysis of cytogenetic alterations in stage III serous ovarian adenocarcinoma reveals a heterogeneous group regarding survival, surgical outcome, and substage. Genes Chromosomes Cancer 2004, 40:342-348.

52. Ghadimi BM, Grade M, Liersch T, Langer C, Siemer A, Fuzesi L, Becker $\mathrm{H}$ : Gain of chromosome 8 q23-24 is a predictive marker for lymph node positivity in colorectal cancer. Clin Cancer Res 2003, 9:1808-1814.

53. De Angelis PM, Stokke T, Beigi M, Flatberg G, Enger M, Haug K, Aass HC, Schjolberg A, Andresen PA, Ariansen S, Bo AS, Mjaland O, Clausen OP: Chromosomal 20q gain in the DNA diploid component of aneuploid colorectal carcinomas. Int / Cancer 2007.

54. Grade M, Becker H, Liersch T, Ried T, Ghadimi BM: Molecular cytogenetics: genomic imbalances in colorectal cancer and their clinical impact. Cell Oncol 2006, 28:7|-84.

55. Terracciano L, Tornillo L: Cytogenetic alterations in liver cell tumors as detected by comparative genomic hybridization. Pathologica 2003, 95:71-82.

56. Steinemann D, Skawran B, Becker T, Tauscher M, Weigmann A, Wingen L, Tauscher S, Hinrichsen T, Hertz S, Flemming P, Flik J, Wiese B, Kreipe H, Lichter P, Schlegelberger B, Wilkens L: Assessment of differentiation and progression of hepatic tumors using array-based comparative genomic hybridization. Clin Gastroenterol Hepatol 2006, 4:|283-I29|.

57. Lau SH, Guan XY: Cytogenetic and molecular genetic alterations in hepatocellular carcinoma. Acta Pharmacol Sin 2005 26:659-665.

58. Jares P, Fernandez PL, Campo E, Nadal A, Bosch F, Aiza G, Nayach I, Traserra J, Cardesa A: PRAD-I/cyclin DI gene amplification correlates with messenger RNA overexpression and tumor progression in human laryngeal carcinomas. Cancer Res 1994, 54:48|3-48I7.

59. Richter H, Braselmann H, Hieber L, Thomas G, Bogdanova T, Tronko $\mathrm{N}$, Zitzelsberger $\mathrm{H}$ : Chromosomal imbalances in post-chernobyl thyroid tumors. Thyroid 2004, I4:106I-1064.

60. Chen X, Knauf JA, Gonsky R, Wang M, Lai EH, Chissoe S, Fagin JA, Korenberg JR: From amplification to gene in thyroid cancer: a high-resolution mapped bacterial-artificial-chromosome resource for cancer chromosome aberrations guides gene discovery after comparative genome hybridization. Am J Hum Genet 1998, 63:625-637.

6I. Schulte KM, Niederacher D, An HX, Staudt S, Simon D, Beckmann MW, Goretzki PE: INT-2 gene amplification in differentiated human thyroid cancer. Exp Clin Endocrinol Diabetes 1996, I 04(Suppl 4): I0 I- 104.

62. Yakut T, Schulten HJ, Demir A, Frank D, Danner B, Egeli U, Gebitekin C, Kahler E, Gunawan B, Urer N, Ozturk H, Fuzesi L: Assessment of molecular events in squamous and non-squamous cell lung carcinoma. Lung Cancer 2006, 54:293-30I.

63. Rao PH, Arias-Pulido $H$, Lu XY, Harris CP, Vargas $H$, Zhang FF Narayan G, Schneider A, Terry MB, Murty VV: Chromosomal amplifications, $3 q$ gain and deletions of $2 q 33-q 37$ are the frequent genetic changes in cervical carcinoma. BMC Cancer 2004, 4:5.

64. Koon N, Zaika A, Moskaluk CA, Frierson HF, Knuutila S, Powell SM, El-Rifai W: Clustering of molecular alterations in gastroesophageal carcinomas. Neoplasia 2004, 6: |43-|49.

65. Bentz M, Bergerheim US, Li C, Joos S, Werner CA, Baudis M, Gnarra J, Merino MJ, Zbar B, Linehan WM, Lichter P: Chromosome imbalances in papillary renal cell carcinoma and first cytogenetic data of familial cases analyzed by comparative genomic hybridization. Cytogenet Cell Genet 1996, 75(I): I7-2I.

66. Hoglund M, Gisselsson D, Soller M, Hansen GB, Elfving P, Mitelman F: Dissecting karyotypic patterns in renal cell carcinoma: an analysis of the accumulated cytogenetic data. Cancer Genet Cytogenet 2004, 153:1-9.

67. Li X, Wang E, Zhao YD, Ren JQ, Jin P, Yao KT, Marincola FM: Chromosomal imbalances in nasopharyngeal carcinoma: a metaanalysis of comparative genomic hybridization results. J Transl Med 2006, 4:4.

68. Seng TJ, Low JS, Li H, Cui Y, Goh HK, Wong ML, Srivastava G, Sidransky D, Califano J, Steenbergen RD, Rha SY, Tan J, Hsieh WS, Ambinder RF, Lin X, Chan AT, Tao Q: The major 8p22 tumor suppressor DLCI is frequently silenced by methylation in both endemic and sporadic nasopharyngeal, esophageal, and cervical carcinomas, and inhibits tumor cell colony formation. Oncogene 2007, 26:934-944.

69. El-Rifai W, Kamel D, Larramendy ML, Shoman S, Gad Y, Baithun S, ElAwady M, Eissa S, Khaled H, Soloneski S, Sheaff M, Knuutila S: DNA copy number changes in Schistosoma-associated and nonSchistosoma-associated bladder cancer. Am J Pathol 2000, | 56:87|-878.

70. Duerr EM, Chung DC: Molecular genetics of neuroendocrine tumors. Best Pract Res Clin Endocrinol Metab 2007, 2 I : I- I4.

7I. Bauer ], Bastian BC: [DNA copy number changes in the diagnosis of melanocytic tumors]. Pathologe 2007.

72. Karhu R, Mahlamaki E, Kallioniemi A: Pancreatic adenocarcinoma - genetic portrait from chromosomes to microarrays. Genes Chromosomes Cancer 2006, 45:721-730.

73. Lee JY, Park YN, Uhm KO, Park SY, Park SH: Genetic alterations in intrahepatic cholangiocarcinoma as revealed by degenerate oligonucleotide primed PCR-comparative genomic hybridization. J Korean Med Sci 2004, 1 9:682-687.

74. Coe BP, Lee EH, Chi B, Girard L, Minna JD, Gazdar AF, Lam S, MacAulay C, Lam WL: Gain of a region on 7 p22.3, containing MADILI, is the most frequent event in small-cell lung cancer cell lines. Genes Chromosomes Cancer 2006, 45: I - I 9.

75. Levan K, Partheen K, Osterberg L, Helou K, Horvath G: Chromosomal alterations in $\mathbf{9 8}$ endometrioid adenocarcinomas analyzed with comparative genomic hybridization. Cytogenet Genome Res 2006, I I 5: 16-22.

76. Bryndorf T, Kirchhoff M, Larsen J, Andreasson B, Bjerregaard B, Westh $H$, Rose $H$, Lundsteen $C$ : The most common chromosome aberration detected by high-resolution comparative genomic hybridization in vulvar intraepithelial neoplasia is not seen in vulvar squamous cell carcinoma. Cytogenet Genome Res 2004, 106:43-48

77. Burnworth B, Popp S, Stark HJ, Steinkraus V, Brocker EB, Hartschuh W, Birek C, Boukamp P: Gain of I I q/cyclin D I overexpression is an essential early step in skin cancer development and causes abnormal tissue organization and differentiation. Oncogene 2006, 25:4399-44I2.

78. Vogelstein B, Kinzler KW: The multistep nature of cancer. Trends Genet 1993, 4:I38-|4I.

79. Seruca R, Suijkerbuijk RF, Gartner F, Criado B, Veiga I, Olde-Weghuis $D$, David L, Castedo S, Sobrinho-Simoes M: Increasing levels of MYC and MET co-amplification during tumor progression of a case of gastric cancer. Cancer Genet Cytogenet 1995, 82: | 40-| 45. 
80. Houldsworth J, Mathew S, Rao PH, Dyomina K, Louie DC, Parsa N, Offit K, Chaganti RS: REL proto-oncogene is frequently amplified in extranodal diffuse large cell lymphoma. Blood 1996, 87:25-29.

8I. Perry A, Nobori T, Ru N, Anderl K, Borell TJ, Mohapatra G, Feuerstein BG, Jenkins RB, Carson DA: Detection of pl6 gene deletions in gliomas: a comparison of fluorescence in situ hybridization (FISH) versus quantitative PCR. J Neuropathol Exp Neurol 1997, 56:999-1008.

82. Nessling M, Solinas-Toldo S, Wilgenbus KK, Borchard F, Lichter P: Mapping of chromosomal imbalances in gastric adenocarcinoma revealed amplified protooncogenes MYCN, MET, WNT2, and ERBB2. Genes Chromosomes Cancer 1998, 23:307-316.

83. Joos S, Menz CK, Wrobel G, Siebert R, Gesk S, Ohl S, Mechtersheimer G, Trumper L, Moller P, Lichter P, Barth TF: Classical Hodgkin lymphoma is characterized by recurrent copy number gains of the short arm of chromosome 2. Blood 2002, 99: $138 \mid-1387$.

84. Penzel R, Hoegel J, Schmitz W, Blaeker H, Morresi-Hauf A, Aulmann S, Hecker E, Mechtersheimer G, Otto HF, Rieker RJ: Clusters of chromosomal imbalances in thymic epithelial tumours are associated with the WHO classification and the staging system according to Masaoka. Int J Cancer 2003, 105:494-498.

85. Liu J, Mohammed J, Carter J, Ranka S, Kahveci T, Baudis M: Distancebased clustering of CGH data. Bioinformatics 2006, 22: | $97 \mid-1978$.

86. Liu J, Ranka S, Kahveci T: Markers improve clustering of CGH data. Bioinformatics 2007, 23:450-457.

\section{Pre-publication history}

The pre-publication history for this paper can be accessed here:

http://www.biomedcentral.com/1471-2407/7/226/pre pub

Publish with Biomed Central and every scientist can read your work free of charge

"BioMed Central will be the most significant development for disseminating the results of biomedical research in our lifetime. "

Sir Paul Nurse, Cancer Research UK

Your research papers will be:

- available free of charge to the entire biomedical community

- peer reviewed and published immediately upon acceptance

- cited in PubMed and archived on PubMed Central

- yours - you keep the copyright

Submit your manuscript here:

http://www.biomedcentral.com/info/publishing_adv.asp
BioMedcentral 